\title{
Introduction: What Goes Wrong in Our Understanding of the Strategy Concept?
}

The term strategy in Chinese originated from war, and the book The Art of War by Sun wu in the Spring and Autumn Period (B.C. 770-221) was the first strategy book to guide military action. In the West, the word "strategy" came from the Greek word "strategos", meaning military generals, later referring to the plan that generals adopted in their command of troops. A good strategy can be a vital weapon to vanquish the enemy as history has witnessed quite a few battles of defeating enemy troops with forces inferior in number, which embodies extraordinary philosophies of military strategists.

The first application of the word strategy in the field of business management was in the book The Practice of Management by Peter Drucker, father of modern management back in 1954. In the 1960s, Chandler (1962) and Ansoff (1965), discussed the role of strategy in corporate management, based on which strategy has been developed and evolved into a discipline.

Strategy, regarded as the decision-making of senior executives in the development of companies and organizations, is significantly decisive to the overall future growth of the organizations. The appropriateness of the strategy is closely related to the survival and development of an organization as it has crucial effect on the direction, adaptability to the surroundings and economic benefits of the organization.

Since Peter Drucker first definition of strategy in 1954, the discipline has gone through development over 60 years, but there is still no clear explanation to answer the question: "What is strategy?" According to the paper published by Ronda-Pupo and Guerras-Martin (2011) on Strategic Management Journal, there are currently 91 definitions of strategy used by scholars. ${ }^{1}$

\footnotetext{
${ }^{1}$ Now the number of definitions may have increased. 
Here are some definitions.

"Strategy is the means by which individuals or organizations achieve their objectives" (Grant 2010).

"Strategy is a pattern of resource allocation that enables firms to maintain or improve their performance" (Barney 1997).

"Strategy is understanding the structure and dynamics of an industry, determining the organization's relative position in that industry, and taking action to either change the industry's structure or the organization's position to improve organizational results" (Oliver 2001).

If we give the full list of all the 91 definitions of strategy, it would be confusing.

We can give a precise definition of strategy as long as we anchor the core elements of the strategy concept, which, however, have very distinctive illustrations in different literature (Koontz 1961, 1980; Chaharbaghi 2007). In fact, the three definitions listed above also show authors' significantly different understandings towards the definition of strategy, and I would like to describe this phenomenon as the issue of having several numbers of definitions. Different definitions involve different understandings of the essence (or connotation) of strategic concept. As the nature of a concept lays the foundation, the concept and its definition of strategy is the basis of strategy discipline. Therefore, if we fail to give a thorough description, the discipline would develop in a biased way.

The strategy concept not only has various definitions of (Cox et al. 2012; Oliver 2001), but also has many elements in the literature. It is confusing as there is no internal links between the elements (Ketchen et al. 2008) and consistency (Hambrick and Frodrideson 2001; Ketchen et al. 2008; Leontiades 1982; Markides 2004; Nag et al. 2007; Oliver 2001), which I conclude as a lack of internal consistency or multi-understanding. This issue involves two fundamental questions about the understanding of the strategy concept. (1) Which elements should be adopted to define strategy, and (2) what is the relationship between the elements.

From 1962 to 2008, up to 20 terms have been used in defining the strategy concept in literature (Ronda-Pupo and Guerras-Martin 2011), and there is a large divergence among those words (Koontz 1961; Knoontz 1980; Chaharbaghi 2007; Ketchen et al. 2008). The confusion brought about by over- or misuse of vocabulary, as I call it, is terminology or semantic confusion (or multi-semantics).

Here, I refer to the three problems in the literature of strategic definition as "Three-multiple problems" (several numbers, multi-understanding, multi-semantics). That is to say, there are many understandings, definitions and vocabulary of the core content of strategic concepts in the literature towards the essential part of the strategy concept.

In addition to the "Three-multiple problems" above, literature on the definition of strategy still has the following problems.

Firstly, the vocabulary used in the literature for defining strategy is not only numerous but also confusing. As I summed up some definitions in literature, I found that different vocabulary emphasizes different aspects, such as strategic goals 
and objectives, strategic means (approaches and tactics) and principles on making strategies. Moreover, different literature (or authors) tends to use different words to express the same meaning; for example, 8 terms are respectively used in 12 papers for strategic goals, and nearly 10 terms are adopted in more than 20 papers on approaches for achieving a goal. Many scholars do not know that different words actually refer to the same core content of the strategy concept.

Secondly, there are some problems in the research methods adopted in the literature on strategic definition. In the absence of clarification of the basic logic, complex research methods, in fact, can merely solve the real problem. In this matter, I agree with Hillman who believed that the theory sometimes could not be simply studied by empirical methods (Hillman 2011).

Thirdly, it seems that literature concerning or studying strategy concept did not draw lessons from practice. Scholars define strategy from their understanding based on the existing literature, which, as mentioned before, has a great deal of problems, and in this case, the research conclusions would not be convincing enough. Therefore, to figure out what is strategy and what are the core elements of strategy concept requires us to step out the existing literature and learn from practice.

As for having the multiple terminologies and meanings in strategy definition, some scholars believe that it is normal for the same noun to be interpreted differently. However, if there are dozens or even hundreds of definitions for a noun, various understandings could raise serious confusion between terms and meanings, which will lead to ambiguity in our comprehension of the core content of the discipline, and the noun itself in ambiguity will lose its academic value. Chaharbaghi (2007) writes that the exponential growth of literature on strategy is directing attention in different ways, is adding greater complexity and is provoking more and more uncertainty while communicating less and less meaning to its audience. Markdall also pointed out in 2004 that the lack of sufficient agreement on the definition of strategy leads to more new definitions, which creates more confusion and disagreement between academics and executives.

It is known that the purpose of science is to apply the theoretical knowledge derived from academic research to social practice to serve business. The current Three-multiple problem in the strategy concept, resulting in great confusion in the strategy discipline, have become the obstacles and bottlenecks in its further development. The Three-multiple problem in literature on the strategy concept draw back academic knowledge from actual demand of companies, and if a key word in strategy embraces too many interpretations and too much ambiguity, it would be pointless in guiding the industry and the corporate sector.

Ronda-Pupo and Guerras-Martin (2011) have called for a strategy definition that requires a language allowing everyone to share, so that people can know what should be the essence of this branch of science. Strategy concept has too many definitions that lead to a variety of perplexities, which require us to at least figure out or understand the causes of the puzzles in order to grasp a better comprehension of the strategy. Even if we cannot completely eliminate all the confusion, reducing it to some extent is also constructive for the development of the strategy discipline. 
Hambrick and Fredrickson also pointed out in 2001 that what actually consists a strategy is missing; therefore, currently the key is achieving a robust and reinforced consistency among the elements of the strategy itself. As it is known from the perspective of science, to obtain this consistency, we first need to find the strategy concept (real) core elements or content, followed by the need to find the relationship between the elements, all of which are the most basic and fundamental preparation.

Baidu interprets the term "definition" as "a brief and accurate description of the meaning of a concept or a word without changing the subject matter itself". If the same word that refers to different meanings (or different words that convey the same meaning) is used in the exchange between people, communication will be difficult and impossible if people fail to have a common understanding towards certain names and terminologies. For this purpose, description of the meaning of names, terms and concepts needs to be made, and clear provisions, in other words definitions, should be given.

Therefore, the study of strategy concept is of importance and necessity from the perspectives of history, the development of strategy discipline, and theoretical guidance on practice. Although some scholars believe that science does not require consensus (Kuhn 1996; Mintzberg 1987a, b: 11), we know that the problems arising from too many strategy definitions are not merely a consensus problem, but serious confusions within the discipline. I am very much in favor of some of the scholars' arguments in the early years that "re-examining the basic definition of strategy" and "improving the accuracy of definition" (Bowman et al. 2002). In particular, study on the language (vocabulary) shared by the strategy concept so that we can find out its nature as a science (Ronda-Pupo and Guerras-Martin 2011).

Pfeffer (1993) once criticized that some journals only rewarded new (strategy) concepts instead of critics on the existing ones. The analysis of this book reviews and analyzes the various definitions of the literature. The main purpose is not to criticize but to sort out the literature through my research and work, to provide systematic understanding towards the nature of strategy to shed light on this concept that has been discussed and argued worldwide by experts for more than half a century.

\section{References}

Ansoff, I. H. (1965). Corporate strategy: An analytic approach to business policy for growth and expansion. New York: McGraw Hill.

Barney, J. B. (1997). Gaining sustaining competitive advantage. Pearson: Addison-Wesley.

Bowman, E. H., Singh, H. \& Thomas, H. (2002). The domain of strategic management: History and evolution. In Handbook of Strategy and Management. Pettigrew A, Thomas H, \& Whittington R (Eds.). London: Sage.

Chaharbaghi, K. (2007). The problematic of strategy: A way of seeing is also a way of not seeing. Management Decision, 45(3), 327-339.

Chandler, A. (1962). Strategy and structure: Chapters in the history of American Industrial Enterprise. Cambridge, MA: MIT Press. 
Cox, M. Z., Daspit, J., Mclaughlin, E., \& Jones, R. J. (2012). Strategic management: Is it an academic discipline? Journal of Business Strategies, 29(1), 25-42.

Grant, R. (2010). Contemporary strategy analysis, text and cases (7th ed.). Hoboken, NJ: Wiley.

Hambrick, D. C., \& Ferdrickson, J. W. (2001). Are you sure you have a strategy? Academy of Management Executive, 15(4), 48-59.

Hillman, A. (2011). Editor's comments: What is the future of theory? The Academy of Management Review, 36(4), 606-608.

Ketchen, D. J., Boyd, B. K., \& Bergh, D. D. (2008). Research methodology in strategic management: Past accomplishments and future challenges. Organizational Research Methods, 11(4), 643-658.

Koontz, H. (1961). The management theory jungle. Journal of the Academy of Management, 4(3), $174-188$.

Koontz, H. (1980). The management theory jungle revisited. Academy of Management Review, 5 (2), 175-187.

Kuhn, T. S. (1996). The structure of scientific revolutions (3rd ed., p. 44). Chicago, IL: University of Chicago Press.

Leontiades, M. (1982). The confusing words of business policy. Academy of Management Review, $7(1), 45-48$.

Markides, C. (2004). What is strategy and how do you know if you have one? Business Strategy Review, 15(2), 5-12.

Mintzberg, H. (1987a). Crafting strategy. Harvard Business Review, 65(4), 66-75.

Mintzberg, H. (1987b). The strategy concept: Five Ps for strategy. California Management Review, 30(1), 11-24.

Nag, R., Hambrick, D. C., \& Chen, M. J. (2007). What is strategic management, really? Inductive derivation of a consensus definition on the field. Strategic Management Journal, 28(9), 935955.

Oliver, R. W. (2001). What is strategy, anyway? Journal of Business Strategy, 22(6), 7-10.

Pfeffer, J. (1993). Barriers to the advance of organizational science: Paradigm development as a dependent variable. Academy of Management Review, 18(4), 599-620.

Ronda-Pupo, G. A., \& Guerras-Martin, L. A. (2011). Dynamics of the evolution of the strategy concept 1962-2008: A co-word analysis. Strategic Management Journal, 33, 162-188.

Open Access This chapter is licensed under the terms of the Creative Commons Attribution 4.0 International License (http://creativecommons.org/licenses/by/4.0/), which permits use, sharing, adaptation, distribution and reproduction in any medium or format, as long as you give appropriate credit to the original author(s) and the source, provide a link to the Creative Commons license and indicate if changes were made.

The images or other third party material in this chapter are included in the chapter's Creative Commons license, unless indicated otherwise in a credit line to the material. If material is not included in the chapter's Creative Commons license and your intended use is not permitted by statutory regulation or exceeds the permitted use, you will need to obtain permission directly from the copyright holder. 